\title{
Nafion- $\mathrm{TiO}_{2}$ composite DMFC membranes: physico-chemical properties of the filler versus electrochemical performance
}

\author{
V. Baglio ${ }^{\mathrm{a}, \mathrm{c}, *}$, A.S. Aricò ${ }^{\mathrm{a}}$, A. Di Blasi ${ }^{\mathrm{a}, \mathrm{c}}$, V. Antonucci ${ }^{\mathrm{a}}$, P.L. Antonucci ${ }^{\mathrm{b}}$, \\ S. Licoccia ${ }^{\text {c }}$, E. Traversa ${ }^{\mathrm{c}}$, F. Serraino Fiory ${ }^{\mathrm{c}}$ \\ ${ }^{a}$ CNR-ITAE Institute, via Salita S. Lucia sopra Contesse 5, 98126 Messina, Italy \\ ${ }^{\mathrm{b}}$ University of Reggio Calabria, Località Feo Di Vito, 89100 Reggio Calabria, Italy \\ c University "Tor Vergata" of Rome, via della Ricerca Scientifica, 00133 Roma, Italy
}

Received 25 February 2004; received in revised form 15 July 2004; accepted 24 July 2004

Available online 22 September 2004

\begin{abstract}
$\mathrm{TiO}_{2}$ nanometric powders were prepared via a sol-gel procedure and calcined at various temperatures to obtain different surface and bulk properties. The calcined powders were used as fillers in composite Nafion membranes for application in high temperature direct methanol fuel cells (DMFCs). The powder physico-chemical properties were investigated by X-ray diffraction (XRD), transmission electron microscopy (TEM), X-ray photoelectron spectroscopy (XPS) and $\mathrm{pH}$ measurements. The observed characteristics were correlated to the DMFC electrochemical behaviour. Analysis of the high temperature conductivity and DMFC performance reveals a significant influence of the surface characteristics of the ceramic oxide, such as oxygen functional groups and surface area, on the membrane electrochemical behaviour. A maximum DMFC power density of $350 \mathrm{~mW} \mathrm{~cm}^{-2}$ was achieved under oxygen feed at $145^{\circ} \mathrm{C}$ in a pressurized DMFC $(2.5 \mathrm{bar}$, anode and cathode) equipped with $\mathrm{TiO}_{2}$ nano-particles based composite membranes.
\end{abstract}

(C) 2004 Elsevier Ltd. All rights reserved.

Keywords: $\mathrm{TiO}_{2}$; DMFC; Composite Nafion membranes; Surface properties; Ceramic fillers

\section{Introduction}

Liquid-fuelled solid-polymer-electrolyte fuel cells are very promising as electrochemical power sources for application in portable devices and transportation, due to their simple design and low environmental impact [1-3]. Yet, despite the practical system benefits, the power density and the efficiency of direct methanol fuel cells (DMFCs) are low compared to polymer electrolyte fuel cells (PEFCs) operating with hydrogen because of the slow methanol oxidation kinetics and the fuel cross-over through the membrane [1-9].

In a pioneering work of Watanabe et al., composite membranes containing Pt-modified inorganic fillers have been shown to facilitate the electrolyte self-humidification by the

\footnotetext{
* Corresponding author. Tel.: +39090 624237; fax: +39 090624247 .

E-mail address: baglio@itae.cnr.it (V. Baglio).
}

recombination of $\mathrm{H}_{2}$ and $\mathrm{O}_{2}$ on the filler surface in PEMFC, at moderate temperatures $\left(80^{\circ} \mathrm{C}\right)$ [5]. Whereas, great efforts have been addressed to the development of polymeric membranes for high temperature DMFCs [10-14]. Operation temperatures above $120^{\circ} \mathrm{C}$ are needed to reduce catalyst poisoning by adsorbed $\mathrm{CO}$ and enhance methanol oxidation rate. Composite membranes containing finely dispersed hygroscopic inorganic oxides $[10,15]$ or heteropolyacids $[16,17]$ effectively show large water retention properties and, consequently, suitable proton conductivity at high temperatures. Similar evidences have been observed when inorganic proton conductors, such as zirconium phosphate, have been used as fillers in DMFC membranes [11]. In particular DMFC operation at temperatures close to $150^{\circ} \mathrm{C}$ has been demonstrated with composite Nafion membranes $[10,11,15,17]$. The adsorption and retention of water on inorganic oxides depends on their surface properties; in particular, the amount of 
co-ordinated water depends on the nature and relative concentration of the surface functional groups $[15,18,19]$.

As a progress of our activity in the development of innovative composite membranes for FCs application, this work deals with an investigation of the influence of morphological and chemical characteristics of $\mathrm{TiO}_{2}$ as filler for Nafion-based composite membranes. $\mathrm{TiO}_{2}$ nanometric powders were inhouse prepared via a sol-gel procedure. Thermal treatments at different temperatures were performed to tailor the oxide powder properties. The electrochemical behaviour of DMFCs equipped with the composite membranes based on $\mathrm{TiO}_{2}$ fillers with different characteristics was investigated.

\section{Experimental}

Nanosized titanium oxide was synthesized by sol-gel hydrolysing an alcoholic solution of $\mathrm{Ti}(\mathrm{O} i \mathrm{Pr})_{4}$ (Aldrich) according to a previously reported procedure [20]. TG analysis of the obtained titania precursor was carried out in a Netzsch TG/DSC/DTA analyser. The precursor was then thermally treated at different temperatures $(500,650$ and $800^{\circ} \mathrm{C}$ ) for $2 \mathrm{~h}$. X-ray diffraction (XRD) analysis was performed with a Philips X-Pert diffractometer using $\mathrm{Cu} \mathrm{K \alpha}$ source operating at $40 \mathrm{kV}$ and $20 \mathrm{~mA}$. Transmission electron microscopy (TEM) of the powders was carried out using a Philips CM12 microscope equipped with $\mathrm{LaB}_{6}$ filament. Xray photoelectron spectroscopy (XPS) measurements were performed using a Physical Electronics (PHI) 5800-01 spectrometer equipped with a monochromatic $\mathrm{Al}$ source operating at $350 \mathrm{~W}$. Element spectra were acquired with pass energy of $11.75 \mathrm{eV}$. The $\mathrm{pH}$ of slurry was measured at room temperature by an ATC compensated $\mathrm{pH}$ probe (Orion). The slurry was composed by $0.5 \mathrm{~g}$ of powder suspended in $0.1 \mathrm{~L}$ of bidistilled water and stirred for $24 \mathrm{~h}$ in the presence of a stream of nitrogen. A steady $\mathrm{pH}$ value was typically obtained after a few tens of minutes and no significant $\mathrm{pH}$ drift was recorded after $24 \mathrm{~h}(<0.05 \mathrm{pH}$ units). The $\mathrm{pH}$ of slurry was sampled in any case after $24 \mathrm{~h}$.

All the composite membranes were prepared by using the recast procedure. The Nafion ionomer was mixed with dimethyl-sulfoxide (DMSO) and $\mathrm{TiO}_{2}$ powder in an ultrasonic bath. The slurry was cast over a glass substrate. The solution was slowly evaporated at $80^{\circ} \mathrm{C}$ under vacuum to achieve a dense polymeric film. This latter was detached from the glass substrate by addition of distilled water and hot pressed between two PTFE foils at $160^{\circ} \mathrm{C}$ for $10 \mathrm{~min}$. Membrane thickness was about $100 \pm 5 \mu \mathrm{m}$. The methanol oxidation catalyst was a $60 \% \mathrm{Pt}-\mathrm{Ru}(1: 1) /$ Vulcan (E-TEK), whereas a 30\% Pt/Vulcan (E-TEK) was used for oxygen reduction. The catalyst layers, including $33 \mathrm{wt} . \%$ Nafion ionomer, were supported on a carbon cloth support coated with a diffusion layer. The platinum loading for all the electrodes used in the experiments was $2 \pm 0.1 \mathrm{mg} \mathrm{cm}^{-2}$. MEAs were prepared by hot pressing the electrodes onto the membrane at $130{ }^{\circ} \mathrm{C}$ and 50 bar. Fuel cell tests were performed

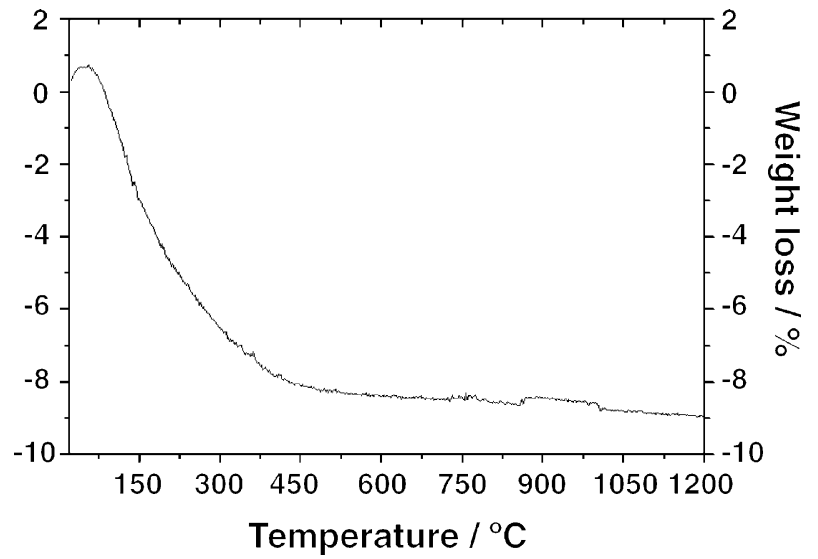

Fig. 1. TG analysis of the titania precursor obtained from the sol-gel procedure.

in a $5 \mathrm{~cm}^{2}$ single cell (GlobeTech, Inc.) connected to a HP 6060B electronic load. A $2 \mathrm{M}$ aqueous solution of methanol and an oxygen stream were preheated at $85^{\circ} \mathrm{C}$ and fed to the cell. The methanol solution was fed into the cell at a flow rate of $2.5 \mathrm{~mL} / \mathrm{min}$ whereas the cathode feed was passed through a humidification bottle with a flow rate of $500 \mathrm{~mL} / \mathrm{min}$. The anode and the cathode back pressure was 2.5 bar at $145^{\circ} \mathrm{C}$. The cell resistance was determined at the various temperatures by the current interrupter method during cell operation at $400 \mathrm{~mA} \mathrm{~cm}^{-2}$.

\section{Results and discussion}

The TG scan of the precursor obtained by sol-gel shows that only a very slight weight loss (1\% wt.) occurs above $450{ }^{\circ} \mathrm{C}$ (Fig. 1). The powders were then calcined at 500, 650 and $800^{\circ} \mathrm{C}$ to obtain crystalline $\mathrm{TiO}_{2}$. Fig. 2 shows the $\mathrm{X}$ ray diffraction patterns of the $\mathrm{TiO}_{2}$ samples after thermal treatments at the three selected temperatures. The presence

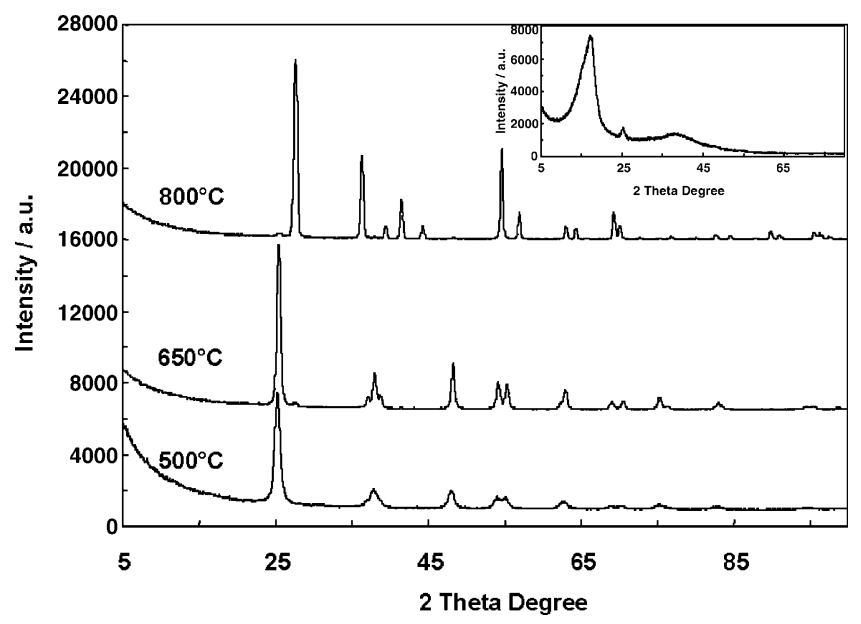

Fig. 2. X-ray diffraction patterns of $\mathrm{TiO}_{2}$ powders calcined at different temperatures; inset: $5 \mathrm{wt} . \% \mathrm{TiO}_{2}$ (calcined at $500^{\circ} \mathrm{C}$ ) based recast Nafion membrane. 
of the crystallographic structure of anatase was observed for the powders calcined at 500 and $650^{\circ} \mathrm{C}$ while the crystallographic structure of rutile was observed for the sample calcined at $800{ }^{\circ} \mathrm{C}[20]$. The crystallite size for the three samples, determined using the Scherrer's equation, was 12, 22 and $39 \mathrm{~nm}$, respectively. The inset of Fig. 2 shows the XRD pattern of the composite Nafion membrane containing $5 \mathrm{wt} . \%$ $\mathrm{TiO}_{2}$ calcined at $500{ }^{\circ} \mathrm{C}$. This composite membrane shows the typical diffraction pattern of Nafion and small reflections due to $\mathrm{TiO}_{2}$ in the anatase phase.

Fig. 3 shows the TEM micrographs of the various $\mathrm{TiO}_{2}$ samples. The particle size is in agreement with the XRD measurements for the powder calcined at the lowest temperature $\left(500^{\circ} \mathrm{C}\right)$, although proper determination of the primary particle dimension was not possible because of the presence of agglomerates. Larger particles were observed in the TEM images of the samples fired at 650 and $800{ }^{\circ} \mathrm{C}$; as expected, the particle size increases progressively with the thermal treatment temperature.

The surface chemistry of the $\mathrm{TiO}_{2}$ powders was investigated by X-ray photoelectron spectroscopy (Figs. 4 and 5). The Ti $2 \mathrm{p}_{3 / 2}$ and Ti $2 \mathrm{p}_{1 / 2}$ photo-electron lines (Fig. 4) occurred at the same binding energies for the three samples
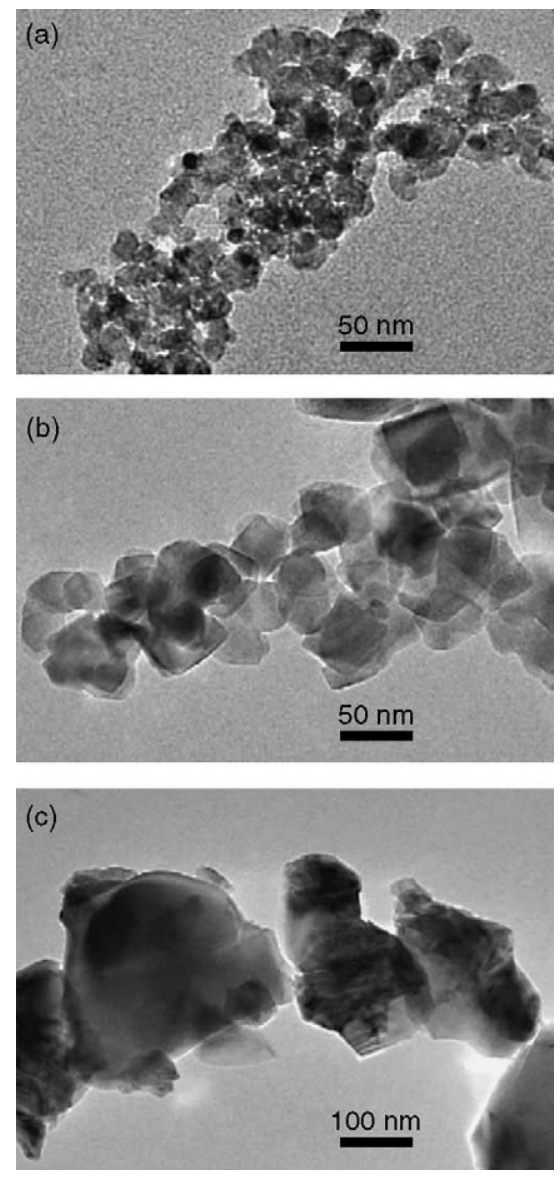

Fig. 3. Transmission electron micrographs of the $\mathrm{TiO}_{2}$ powders calcined at $500{ }^{\circ} \mathrm{C}(\mathrm{a}), 650^{\circ} \mathrm{C}$ (b) and $800^{\circ} \mathrm{C}$ (c) employed in the preparation of the composite membranes.

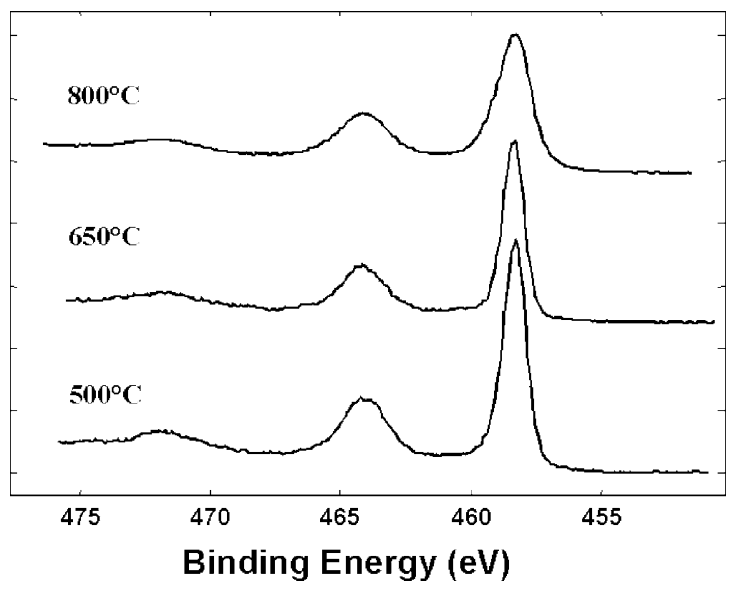

Fig. 4. Comparison of the Ti 2p X-ray photoelectron peaks for the $\mathrm{TiO}_{2}$ powder calcined at different temperatures.
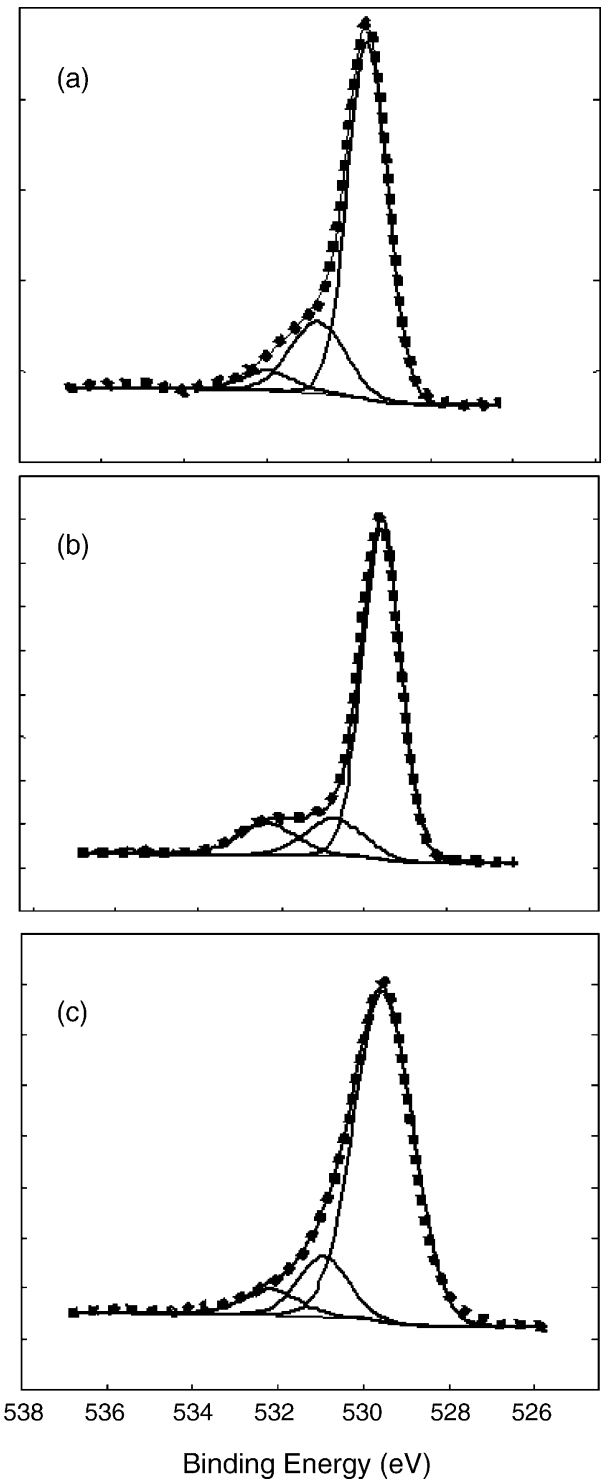

Fig. 5. Curve fitting of $\mathrm{O} 1 \mathrm{~s} \mathrm{X}$-ray photoelectron peaks for the $\mathrm{TiO}_{2}$ powder calcined at $500^{\circ} \mathrm{C}\left(\right.$ a), $650{ }^{\circ} \mathrm{C}$ (b) and $800^{\circ} \mathrm{C}$ (c). 
Table 1

B.E. and relative peak areas of O 1s species from curve-fitted XPS spectra for the various $\mathrm{TiO}_{2}$ powders

\begin{tabular}{lll}
\hline Species & B.E. $(\mathrm{eV})$ & Relative peak area $(\%)$ \\
\hline $\mathrm{TiO}_{2}$ calcined at $500^{\circ} \mathrm{C}$ & $\mathrm{O} 1 \mathrm{~s}$ & \\
& 529.54 & 72.91 \\
& 530.76 & 21.08 \\
& 531.98 & 5.01 \\
$\mathrm{TiO}_{2}$ calcined at $650^{\circ} \mathrm{C}$ & $\mathrm{O} 1 \mathrm{~s}$ & \\
& 529.56 & 75.52 \\
& 530.71 & 12.61 \\
& 532.33 & 11.87 \\
$\mathrm{TiO}_{2}$ calcined at $800{ }^{\circ} \mathrm{C}$ & $\mathrm{O} 1 \mathrm{~s}$ & \\
& 529.53 & 84.23 \\
& 530.93 & 11.20 \\
& 532.17 & 4.57 \\
\hline
\end{tabular}

(458.4 $\pm 0.2 \mathrm{eV}$ and $463.94 \pm 0.2 \mathrm{eV}$, respectively). This B.E. is typical of $\mathrm{TiO}_{2}$ compounds; accordingly, the photoelectron peaks are mainly associated to the main Ti sites from the titania framework with small influence from surface defects. The $\mathrm{O} 1 \mathrm{~s}$ region of the XPS spectra (Fig. 5) showed similar values of B.E. for the main peak (Table 1) of the various $\mathrm{TiO}_{2}$ samples $(529.6 \mathrm{eV})$. However, the $\mathrm{TiO}_{2}$ powders treated at 500 and $650{ }^{\circ} \mathrm{C}$ and characterized by the anatase structure showed a larger content of oxygen species at higher binding energies. These peaks, centered at about $530.8 \mathrm{eV}$ (Fig. 5), are associated with the presence of surface $\mathrm{OH}$ groups. Their intensity is not very high with respect to the main $\mathrm{O} 1 \mathrm{~s}$ peak deriving from crystalline $\mathrm{TiO}_{2}$ framework. However, the occurrence of $\mathrm{Ti}-\mathrm{OH}$ groups on the surface imparts a slight acidic behaviour to the fillers [19]. This finding was confirmed by the measurements of the $\mathrm{pH}$ of slurry for the titania powders; the higher the temperature of the powder calcinations, the higher the measured values of the $\mathrm{pH}$ of slurry, up to basic value for the powder heated to $800^{\circ} \mathrm{C}$ (Table 2). The XPS analysis showed that the ratio between the intensities of the acidic $\mathrm{Ti}-\mathrm{OH}$ surface species and the neutral $-\mathrm{O}-\mathrm{Ti}-\mathrm{O}-$ species from the framework was slightly larger for the sample treated at the lowest temperature $\left(500{ }^{\circ} \mathrm{C}\right)$. The more acidic behaviour of this sample with respect to the powder heated to $650^{\circ} \mathrm{C}$ can be also ascribed to its smaller particle size, and thus its larger surface area (Fig. 5a and b). The concentration of surface $\mathrm{OH}$ groups was lower for the sample calcined at $800^{\circ} \mathrm{C}$ and having the rutile structure, because of the water elimination reactions induced by the thermal treatment (Fig. 5c). Yet, a small peak was still present in the higher binding energies region of the $\mathrm{O} 1 \mathrm{~s}$ spectrum.

Table 2

Physico-chemical properties of $\mathrm{TiO}_{2}$ powders

\begin{tabular}{llll}
\hline Filler & $\begin{array}{l}\text { Crystallographic } \\
\text { structure }\end{array}$ & $\begin{array}{l}\text { Mean particle } \\
\text { size }\end{array}$ & $\begin{array}{l}\text { pH of } \\
\text { slurry }\end{array}$ \\
\hline $\mathrm{TiO}_{2}$ calcined at $500^{\circ} \mathrm{C}$ & Anatase & 12 & 5.3 \\
$\mathrm{TiO}_{2}$ calcined at $650^{\circ} \mathrm{C}$ & Anatase & 22 & 6.2 \\
$\mathrm{TiO}_{2}$ calcined at $800^{\circ} \mathrm{C}$ & Rutile & 39 & 9.0 \\
\hline
\end{tabular}

${ }^{\mathrm{a}}$ From XRD; ( 1010 ) reflection for anatase and (1 111 ) reflection for rutile.
These surface oxygen species are believed to be responsible of the water co-ordination on the filler surface during membrane operation above $100^{\circ} \mathrm{C}$, probably assisting at different extents the proton conduction $[18,19]$. The XPS O 1s peak component at higher B.E.s (at about $532 \mathrm{eV}$ ) could be associated with the presence of surface oxygen containing carbonaceous species adsorbed from the atmosphere.

To evaluate the influence of physico-chemical properties of the inorganic filler on the electrochemical behaviour, composite recast Nafion membranes containing $5 \mathrm{wt} . \% \mathrm{TiO}_{2}$ powder calcined at the three different temperatures $(500,650$, $800^{\circ} \mathrm{C}$ ) were prepared and tested in fuel cell devices. Fig. 6 shows the polarization curves recorded at $145^{\circ} \mathrm{C}$ for the various MEAs equipped with the composite Nafion membranes containing $5 \mathrm{wt} . \% \mathrm{TiO}_{2}$ calcined at different temperatures. The inset of Fig. 6 shows the variation of cell resistance as a function of the operating temperature for DMFCs employing these composite membranes. Since the nature of the surface functional groups is essentially the same for the three inorganic fillers, the variation in performance and conductivity can be mainly attributed to the different particle size, and thus to the different specific surface areas (SSA). A powder with a large specific surface area is characterized by a large number of adsorbing sites. Accordingly, a significant number of water molecules will be coordinated by the $\mathrm{OH}$ groups present on the surface of $\mathrm{TiO}_{2}$ particles, promoting the proton transport through the membrane at high temperatures.

No specific role appeared to be played by the bulk structure. The membranes treated at 650 and $800^{\circ} \mathrm{C}$, containing fillers with the anatase and rutile structure, respectively, showed similar electrochemical properties. In agreement, the XPS analysis showed for these samples essentially similar surface functionalities independently from the crystallographic structure. The main differences among these two powders consisted in the relative concentration of the functional groups capable of water coordination $[15,18,19]$, as determined by XPS. The specific surface area can be roughly evaluated from particle size [21], by assuming an approximately spherical shape for the primary particles; applying

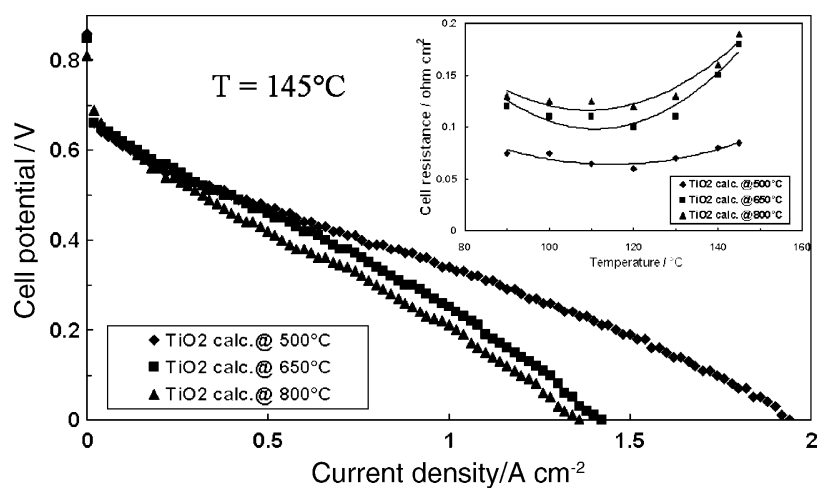

Fig. 6. Variation of cell resistance (inset) as a function of the operating temperature and polarization curves at $145^{\circ} \mathrm{C}$ for the various MEAs equipped with the composite Nafion membranes containing $5 \mathrm{wt}$. $\% \mathrm{TiO}_{2}$ calcined at different temperatures. $2 \mathrm{M}$ Methanol feed, 2.5 bar; oxygen feed, 2.5 bar. 


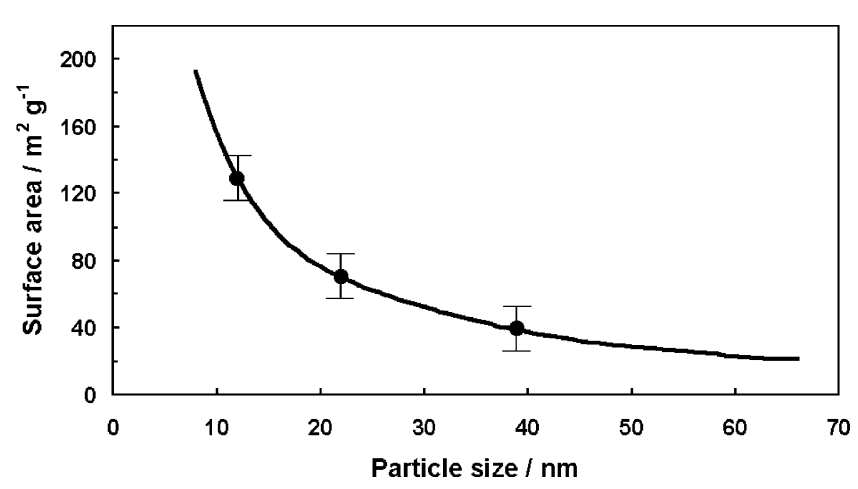

Fig. 7. Variation surface area as a function of particle size for the various $\mathrm{TiO}_{2}$ powders.

such model a sudden increase in SSA $\left(\mathrm{m}^{2} / \mathrm{g}\right)$ would occur for particle sizes smaller than about $20 \mathrm{~nm}$ (Fig. 7); this may explain the improvement in performance and conductivity of the membranes based on $\mathrm{TiO}_{2}$ powder with an average particle size close to $11 \mathrm{~nm}$ (Fig. 6).

A maximum power density of $350 \mathrm{~mW} \mathrm{~cm}^{-2}$ was obtained at $145^{\circ} \mathrm{C}$ with the cell equipped with the composite membrane containing $\mathrm{TiO}_{2}$ calcined at $500{ }^{\circ} \mathrm{C}$ (Fig. 8). The cells equipped with the membranes with larger $\mathrm{TiO}_{2}$ particles were also operated up to $145^{\circ} \mathrm{C}$, but, the performance did not increase significantly going from 130 to $145^{\circ} \mathrm{C}$ (not shown) because of a significant increase in cell resistance (Fig. 6, inset).

A considerable aspect for a successful application of a composite polymer electrolyte in fuel cell devices is the performance stability. Accordingly, the DMFC equipped with Nafion membrane containing $\mathrm{TiO}_{2}$ calcined at $500^{\circ} \mathrm{C}$ was subjected to 1 month operation with daily-cycles of start up and shut down. The recorded cell current density, at a cell potential of $0.4 \mathrm{~V}$, for a typical day of operation is reported in Fig. 9. A similar behaviour was recorded during all the days of operation. The slight decrease of performance with time was probably due to a poisoning effect by methanolic residues at the anode as well as the formation of oxide species on the cathode surface [22]. After discharging the cell by feeding

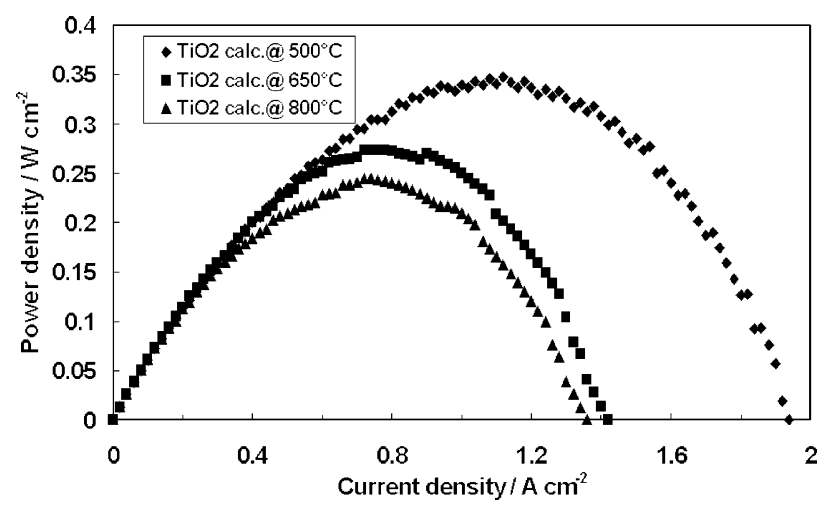

Fig. 8. Power density curves at $145^{\circ} \mathrm{C}$ for the various MEAs equipped with the composite Nafion membranes containing $5 \mathrm{wt} \% \mathrm{TiO}_{2}$ calcined at different temperatures. $2 \mathrm{M}$ Methanol feed, $2.5 \mathrm{bar}$; oxygen feed, $2.5 \mathrm{bar}$.

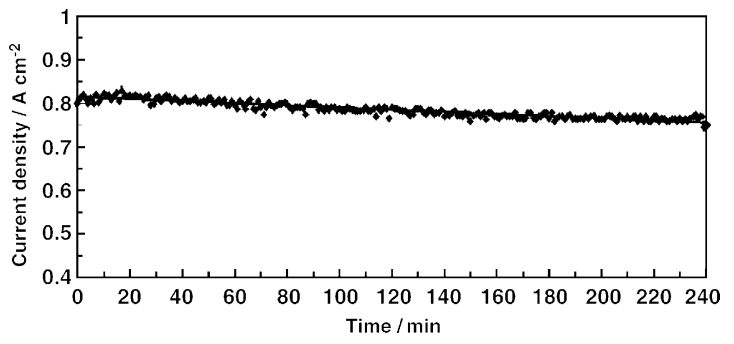

Fig. 9. Variation of DMFC current density for the MEA based on composite recast Nafion membrane containing $\mathrm{TiO}_{2}$ calcined at $500^{\circ} \mathrm{C}$ as a function of time during a day operation under potentiostatic control. Cell voltage $0.4 \mathrm{~V}$, temperature $145^{\circ} \mathrm{C}, 2 \mathrm{M}$ methanol feed, 2.5 at. rel., oxygen feed, 2.5 at. rel.

water at the anode, the day after the cell regained the initial performance.

\section{Conclusions}

The influence of physico-chemical properties of $\mathrm{TiO}_{2}$ inorganic filler on the electrochemical behaviour of a DMFC based on composite membranes was investigated. It clearly appears that, for materials characterized by similar surface functional groups, the effect of the filler surface area becomes prevailing in determining the water retention properties of the composite membranes at high temperature. This effect appears to be associated to the larger number of wateradsorbing acidic sites on the filler surface. As expected, the surface properties play a role more important than the crystalline structure of the filler, since the water molecules acting as promoters towards the proton migration are effectively coordinated by the surface groups. A further increase of the electrochemical performance may thus be achieved by appropriate tailoring of the surface characteristics of the inorganic filler.

\section{References}

[1] S. Wasmus, A. Kuver, J. Electroanal. Chem. 461 (1999) 14.

[2] A.S. Aricò, S. Srinivasan, V. Antonucci, Fuel Cells 2 (2001) 133.

[3] M. Neergat, D. Leveratto, U. Stimming, Fuel Cells 2 (2002) 25.

[4] X. Ren, M.S. Wilson, S. Gottesfeld, J. Electrochem. Soc. 143 (1996) 12.

[5] M. Watanabe, H. Uchida, Y. Seki, M. Emori, P. Stonehart, J. Electrochem. Soc. 143 (1996) 3847.

[6] O. Savadogo, J. New Mater. Electrochem. Syst. 1 (1998) 47.

[7] T.A. Zawodzinski, J. Davey, J. Valerio, S. Gottesfeld, Electrochim. Acta 40 (1995) 297.

[8] N. Miyake, J.S. Wainright, R.F. Savinell, J. Electrochem. Soc. 148 (2001) 898.

[9] B. Bonnet, D.J. Jones, J. Roziere, L. Tchicaya, G. Alberti, M. Casciola, L. Massinelli, B. Bauer, A. Peraio, E. Ramunni, J. New Mater. Electrochem. Syst. 3 (2000) 87.

[10] A.S. Aricò, P. Cretì, P.L. Antonucci, V. Antonucci, Electrochem. Solid State Lett. 1 (1998) 66.

[11] C. Yang, S. Srinivasan, A.S. Aricò, P. Cretì, V. Baglio, V. Antonucci, Electrochem. Solid State Lett. 4 (2001) 31. 
[12] K.T. Adjemian, S.L. Lee, S. Srinivasan, J. Benziger, A.B. Bocarsly, J. Electrochem. Soc. 149 (2002) 256.

[13] K.D. Kreuer, J. Membr. Sci. 185 (2001) 29

[14] J. Kerres, W. Zhang, L. Jorissen, V. Gogel, J. New Mater. Electrochem. Syst. 5 (2002) 97.

[15] A.S. Aricò, V. Baglio, A. Di Blasi, P. Cretì, P.L. Antonucci, V. Antonucci, Solid State Ionics 161 (2003) 251.

[16] B. Tazi, O. Savadogo, J. New Mater. Electrochem. Syst. 4 (2001) 187.

[17] P. Staiti, A.S. Aricò, V. Baglio, F. Lufrano, E. Passalacqua, V. Antonucci, Solid State Ionics 145 (2001) 101.
[18] A.S. Aricò, V. Baglio, A. Di Blasi, V. Antonucci, Electrochem. Commun. 5 (2003) 862.

[19] A.S. Aricò, V. Baglio, A. Di Blasi, E. Modica, P.L. Antonucci, V. Antonucci, J. Power Sources 128 (2004) 113.

[20] E. Traversa, M.L. Di Vona, S. Licoccia, M. Sacerdoti, M.C. Carotta, L. Crema, G. Martinelli, J. Sol-Gel Sci. Technol. 22 (2001) 167.

[21] A.S. Aricò, P.L. Antonucci, E. Modica, V. Baglio, H. Kim, V. Antonucci, Electrochim. Acta 47 (2002) 3723.

[22] P. Piola, P. Zelenay, Proceedings of the 205th Meeting of The Electrochemical Society, San Antonio, TX, May 9-14 2004 (abstract 338). 